\title{
Assessing the Vulnerability of Public-Supply Wells to Contamination: Glacial Aquifer System in Woodbury, Connecticut
}

The U.S. Geological Survey's National Water-Quality Assessment (NAWQA) Program found, in studies from 1991 to 2001, low levels of mixtures of contaminants in groundwater near the water table in urban areas across the Nation. Contaminants were detected less frequently in deeper groundwater typically developed for public supply (Hamilton and others, 2004). The proximity of contaminant mixtures to underlying public water-supply sources, however, prompted the NAWQA Program to begin intensive studies in 2001 to assess the vulnerability of public-supply wells to contamination. Specifically, pathways and processes by which contaminants reach public-supply wells in nine aquifer systems across the country are being investigated. Scientists are studying the processes below land surface that control whether contaminants are delayed, transformed, or mobilized; they are also investigating how human activities can affect the vulnerability of public-supply wells to contamination.

This fact sheet highlights findings from the vulnerability study of a public-supply well in Woodbury, Connecticut (Starn and Brown, 2007; Brown and others, 2009), in the western part of the State. The well typically produces water at the rate of 72 gallons per minute from the glacial aquifer system in the Pomperaug River Basin. Historic water-quality problems concerning this well include the presence of chlorinated solvents (Mazzaferro, 1986; Geraghty \&
Miller, 1979) and several gasoline-related compounds (Sovereign Consulting, Inc., 2004) that have been associated with "the commercial area" (several light industrial or commercial properties in an area of businesses where hazardous materials and petroleum products are used and stored). Samples collected (prior to treatment) from the public-supply well for the current study contained several types of undesirable constituents, including 11 volatile organic compounds (VOCs), nitrate, pesticides, uranium, and radon. Most of these constituents were detected at concentrations below drinking-water standards, where such standards exist. Only concentrations of the VOC trichlorethylene (TCE) exceeded the Maximum Contaminant Level (MCL) of 5 micro-
The glacial aquifer system in the Pomperaug River Basin is made up of glacial deposits and fractured bedrock. Stratified (layered) sediments deposited by glacial meltwater fill in the valley underlying the Town of Woodbury. Such deposits are generally the most productive sources of groundwater in New England. Fractured bedrock lies beneath the valley and the adjacent uplands. Glacial till (a dense mixture of different-sized rock particles in a fine-grained matrix) blankets the bedrock surface in the uplands and in some areas beneath the stratified glacial deposits in the valley. Together, stratified glacial deposits and till are referred to as "glacial deposits" in this fact sheet. Bedrock beneath the valley is composed of basalt and sedimentary rocks (shale, siltstone, conglomerate, and organic-rich limestone), whereas bedrock in the uplands includes basalt and metamorphic and granitic rocks. Recharge to the aquifer system originates as rainfall or as stream water that infiltrates to the water table. In the uplands, infiltrating water reaches the water table and then flows laterally through till to upland streams or downward into bedrock fractures. Water eventually flows from the bedrock through the sides and bottom of the filled valley into the glacial deposits. Groundwater in the valley discharges to streams, ponds, or wells in the area. The public-supply well selected for study is open to the glacial deposits from 45 to 60 feet below land surface. It supplies water to about 2,000 Woodbury residents who live in the valley bottom. Most of the groundwater withdrawn in the study area is returned to the subsurface as flow through septic-tank drainfields, because all residences and businesses in Woodbury are unsewered and use onsite septic systems to treat human waste. 
grams per liter $(\mu \mathrm{g} / \mathrm{L})$ established by the U.S. Environmental Protection Agency for drinking water. Radon concentrations exceeded a proposed - but not finalizedMCL of 300 picocuries per liter ( $\mathrm{pCi} / \mathrm{L})$.

Some of the contaminants detected in the public-supply well and in nearby monitoring wells are anthropogenic; that is, introduced by human activities. Specifically, elevated nitrate concentrations are associated with septic-system leachate in the study area. The types of pesticides detected are commonly linked to lawn maintenance in urban and residential areas. VOCs are frequently used as solvents or gasoline components. Other contaminants-such as uranium, radon, and arsenic - occur naturally in the sediments and rocks that make up the aquifer system.

Overall, the study findings point to four main factors that affect the movement and fate of contaminants and the vulnerability of the public-supply well in Woodbury: (1) groundwater age (how long ago water entered, or recharged, the aquifer); (2) the percentage of recharge received through urban areas; (3) the percentage of recharge received through dry wells and their proximity to the public-supply well; and (4) geochemical processes within the aquifer system; that is, processes that affect the amounts and distribution of chemical substances in aquifer sediments and groundwater. Study findings are intended to help water managers, drinking-water suppliers, and policymakers to better understand how and why contamination of public-supply
Figure 1. A groundwater flow model was used to simulate age distribution of water (the mixture of water of different ages) produced by the selected supply well in Woodbury, Connecticut. "Age" refers to the time elapsed since water entered the groundwater system

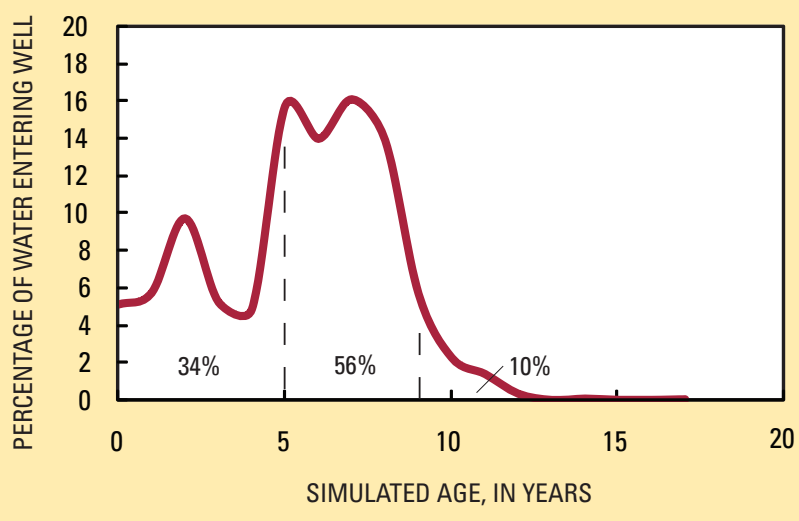
as recharge at the water table. Percentages under curve indicate proportion of total water in three age ranges. Water in this system is young relative to groundwater found in many of the other aquifer settings studied as part of the NAWQA Program. wells occurs and whether water quality may improve or degrade. Additionally, study findings may be used to evaluate the likely effect of various pumping, resource-development, and land-management scenarios on the quality of water produced by the public-supply well.

\section{Well Vulnerability Results From Very Young Age of Groundwater}

Groundwater age refers to the elapsed time since water entered or "recharged" an aquifer at the water table. Because water in an aquifer typically flows downward and laterally over time, it is expected that the very youngest water will be found near the water table and older water will be found at greater depths. The proportion of young water produced by the public-supply well

\section{Study Design}

A computer model of groundwater flow was constructed at a regional scale to estimate the "zone of contribution" to the public-supply well (Lyford and others, 2007). The zone of contribution is the three-dimensional volume of the aquifer material through which groundwater flows from the time it enters the groundwater system at the water table until it eventually discharges at the public-supply well. A network of 35 monitoring wells was installed in or near the simulated zone of contribution to the well in stratified glacial deposits, glacial till, and fractured bedrock to understand groundwater flow and geochemistry along general directions of groundwater flow to the well (Brown and others, 2009). Water samples were collected from the 35 new monitoring wells, an existing monitoring well, and the supply well during 2002 through 2006 and analyzed for naturally occurring contaminants (such as uranium, radon, and arsenic) and contaminants resulting from human activities (such as volatile organic compounds, pesticides, phosphorus, and nitrogen). Other water-quality parameters (such as major ions, age-dating tracers, and selected stable isotopes) were analyzed for to improve understanding of sources of water and reactions affecting the chemical composition of groundwater. Finally, a more detailed, local-scale computer model of groundwater flow to the public-supply well was constructed to refine the estimated area contributing recharge to the well and to calculate the traveltime of water entering the public-supply well (Starn and Brown, 2007). (water that recharged within the last 60 years) is important for determining the vulnerability of the well to contaminants resulting from human activities. Groundwater older than about 60 years recharged the aquifer system before the use of man-

To understand the blend of water of different ages (or "age distribution of water") produced by the public-supply well, a computer-model simulation of groundwater flow was used to estimate the traveltime (or age) of water particles entering the public-supply well along the 15 -foot length of the well screen. About 34 percent of the simulated flow to the well consists of water that is younger than 5 years (fig. 1), which recharged in the valley. About 56 percent of the water is from 5 to 9 years old, and the remaining 10 percent of the water is older than 9 years. Computer simulation indicates that all of the water produced by the supply well recharged the aquifer system within the last 60 years.

Because computer-simulated traveltimes of water flowing from fractured bedrock into the glacial deposits may be artificially short (Starn and Brown, 2007), additional methods were used to determine water age. Tritium is an age tracer that was used to determine whether precipitation recharged local aquifers before or after significant atmospheric release of tritium in the early $1950 \mathrm{~s}$ - a result of nuclear testing. Tritium concentrations confirm that most water in the glacial aquifer system is young, but water from one deep bedrock monitoring well likely recharged before 1952. Chemical modeling indicates that less than 2 percent of water produced by the publicmade chemicals became prevalent. 


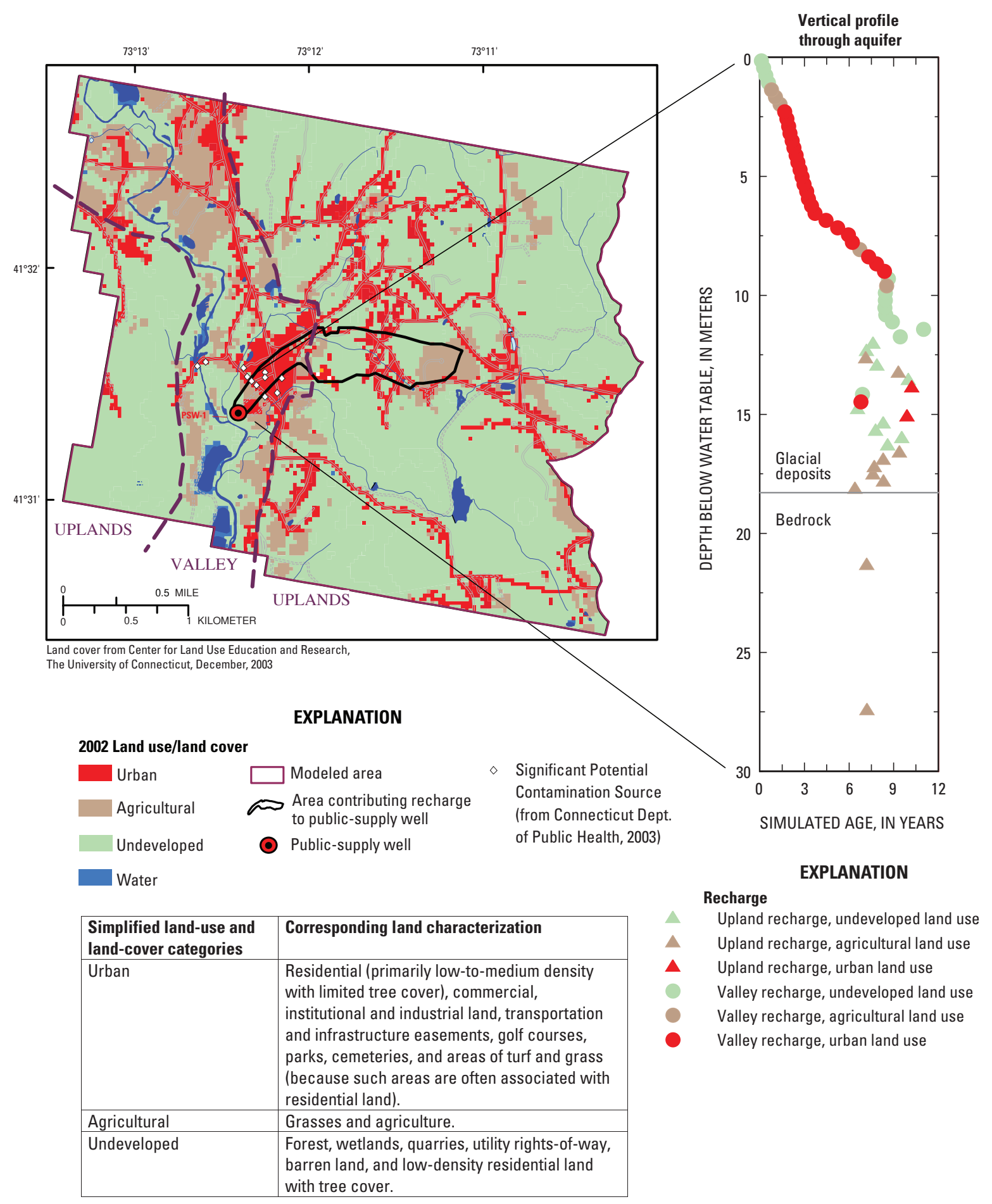

Figure 2. A computer model simulating groundwater flow in the glacial aquifer system was used to track water "particles" (or parcels) from a vertical profile through the aquifer back to where the particles recharged at the water table. Using this technique, the water particles were categorized according to traveltime and land cover at the point of recharge. The chemical quality of each particle of water is determined in part by the land cover through which the water (originating as precipitation) seeped before it reached the water table. The resulting vertical profile of groundwater in the glacial aquifer system shows that water age generally increases with depth. Water that recharged in the valley predominates at shallow depths, whereas deeper water originated as recharge in the uplands. All water in the glacial portion of the vertical profile at this location and some of the bedrock water is eventually captured by the public-supply well; thus, water produced at the wellhead is mixed in age and also is influenced by the various land uses within the area contributing recharge to the well. 
supply well is old water from the deep bedrock. Such a small percentage of old groundwater entering the public-supply well offers little potential for dilution of young waters containing contaminants from human activities.

\section{Urban Sources of Contamination Affect Well Vulnerability}

The area contributing recharge to the public-supply well is the zone where water that eventually reaches the publicsupply well enters the groundwater system at the water table (see fig. 2). Urban land in the area contributing recharge to the public-supply well includes various potential sources of contamination, as inventoried by the Connecticut Department of Public Health (2003) - many of which are in the commercial area that is about one-quarter mile directly upgradient from the public-supply well (meaning that water is flowing from the commercial area toward the supply well). Manmade contaminants detected in the glacial aquifer system during the current study include solvents, fuel components, road salt, and septic-system leachate.

Volatile organic compounds (VOCs) were widely detected in water samples from monitoring wells throughout the study area (in 32 of the 36 wells sampled) and from the public-supply well. Shallow groundwater that originated as recharge through urban areas in the valley (fig. 2) typically had higher concentrations and more detections of VOCs than did groundwater from the deep glacial deposits or fractured bedrock that originated mainly as recharge through agricultural and undeveloped land. The chlorinated solvents TCE and perchloroethylene (PCE) were the only two VOCs detected above drinking-water standards in any of the 36 monitoring wells sampled for this study. Chlorinated solvents in urban areas are used for purposes such as degreasing and dry cleaning, and also as ingredients in septic-tank cleaning products. PCE concentrations were highest in samples from several monitoring wells downgradient from the commercial area, with an $11-\mu \mathrm{g} / \mathrm{L}$ concentration in one well that exceeded the MCL $(5 \mu \mathrm{g} / \mathrm{L})$. TCE was detected in 33 percent of the monitoring wells; concentrations at three wells (maximum concentration, $25 \mu \mathrm{g} / \mathrm{L}$ ) exceeded the MCL $(5 \mu \mathrm{g} / \mathrm{L})$. TCE concentrations in samples collected from the public-supply well before treatment ranged from 4.3 to $16 \mu \mathrm{g} / \mathrm{L}$. Once in the subsurface, PCE and TCE are persistent. Although remediation efforts have lessened concentrations, TCE and PCE have been detected in the aquifer since the late 1970s.

Methyl tert-butyl ether (MTBE) was the most frequently detected VOC during this study. The main source of MTBE in the study area is a plume caused by a fuel spill at a gas station in the commercial area. The sale and use of MTBE was banned in Connecticut after January 1, 2004. Concentrations of MTBE in samples from the public-supply well peaked at $29 \mu \mathrm{g} / \mathrm{L}$ in 2005 , then decreased to less than $2 \mu \mathrm{g} / \mathrm{L}$ by July 2006 as a result of groundwater remediation efforts (Scott Beals, Sovereign Consulting, Inc., written commun., 2007).

Chloroform was the second most frequently detected compound and was found in 45 percent of the wells sampled. Chloroform is a VOC that can be formed as a byproduct of chlorination. The wells in which chloroform was detected generally coincide with areas of publicly supplied water, where distribution pipes carry chlorinated water (and could poten- tially be leaking) and commercial and residential properties discharge chlorinated water to septic-tank drainfields.

Shallow groundwater in the glacial deposits has higher concentrations of dissolved solids than deep water does. Further chemical analyses indicate these shallow waters are affected by road salt and by septic-system leachate. Both types of contamination result in water with elevated sodium, calcium, and chloride concentrations. Septic-system leachate was distinguished from road-salt contamination by generally elevated concentrations of nitrate (3 to $19 \mathrm{mg} / \mathrm{L}$ (milligrams per liter)) and dissolved organic carbon ( 0.5 to $89 \mathrm{mg} / \mathrm{L}$ ), as well as known proximity of wells to septic systems (fig. 3). Water from wells affected by septic-system leachate also contained a lower ratio of chloride to bromide ions than waters affected by road salt, as well as relatively high concentrations of boron (12 to 155 $\mu \mathrm{g} / \mathrm{L}$ ). Boron is present in domestic sewage as a residue of laundry detergents. Wells affected by septic-system leachate generally had higher concentrations of trace elements than samples from shallow glacial deposits that were relatively unaffected by human contaminant sources.

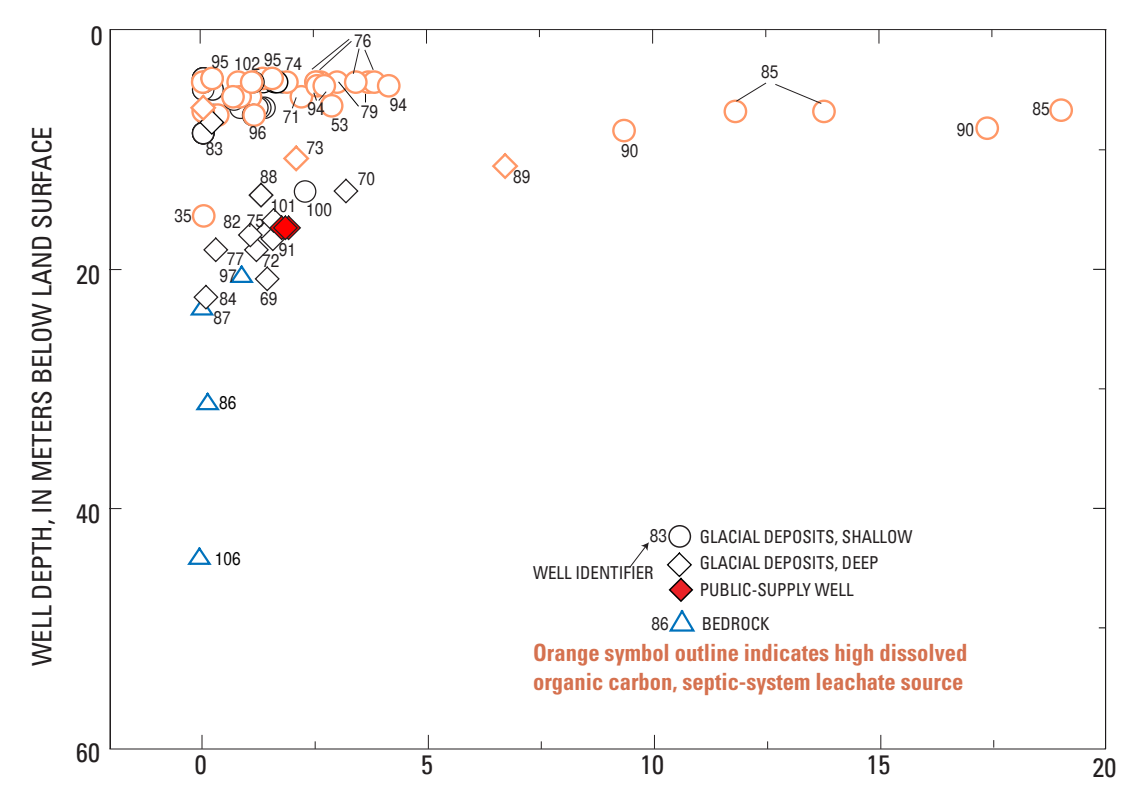

NITRATE PLUS NITRITE CONCENTRATION, IN MILLIGRAMS PER LITER AS NITROGEN

Figure 3. A substantial number of monitoring wells screened in the shallow glacial deposits were found to be affected by septic-system leachate, as determined by high dissolved organic carbon content, generally elevated nitrate concentrations, and other chemical criteria. In localized zones of the aquifer where concentrations of dissolved oxygen were low (less than $0.5 \mathrm{mg} / \mathrm{L}$ ), nitrate had been converted to nitrogen gas by bacterial action, hence the low nitrate concentrations seen in septic-leachate-affected wells on the left end of the graph. 
Although the public-supply well does not have all the characteristics of a well affected by septic-system leachate, it does have a boron concentration and a ratio of chloride to bromide ions that is consistent with septic-system sources. To delineate the impact of septicsystem leachate on water quality in the public-supply well, a mixing model was employed that used nitrate concentrations and stable isotope ratios to estimate sources of nitrate relative to two endpoints. One endpoint was represented by a monitoring well in a forested setting; the other endpoint was represented by a monitoring well in an urban setting downgradient from a septic-tank drainfield. The plotting location of the public-supply well water chemistry along the mixing line indicated that up to 15 percent of the nitrate in water from the supply well was likely from septic-system leachate (McMahon and others, 2008).

\section{Dry Wells Serve as Fast Pathways for Movement of Contaminants Into the Public-Supply Well}

To reduce stormwater runoff in Woodbury, water from the parking lots and pavement is channeled into dry wells - drains that shunt water directly into the aquifer system, bypassing the soil and unsaturated zones. Using the groundwater flow model to track water particles originating at dry wells in the commercial area, USGS scientists concluded that approximately 16 percent of the water produced by the public-supply well is derived from runoff captured by these drains. The residence time for water from the commercial area is about 1.5 to less than 4 years, owing to the nearness of this area to the public-supply well and the capacity of the stratified glacial sediments to rapidly transmit water. Dry wells have the potential to enhance contaminant movement to the supply well because (1) they divert runoff directly into the groundwater system, bypassing the contaminant filtration and degradation processes that may occur in the unsaturated zone; (2) they capture all precipitation in this area as runoff (rather than losing some of the precipitation as overland flow to streams or as transpiration by plants), creating an area of higher recharge relative to other areas; and (3) the stormwater runoff transports contaminants that have accumulated on



USGS scientist Jason Lewis collects a chemical-quality sample from a well near Woodbury, Connecticut. (Photograph by Craig Brown, U.S. Geological Survey.)

the pavement, including road salt during winter months. Because of the dry wells, a chemical spill or new contaminant source in the commercial area would rapidly affect the water quality of the publicsupply well. These findings indicate that stormwater-control methods cannot be considered separately from groundwater quality-they are linked.

\section{Natural Geochemical Conditions in Aquifer System Affect the Fate of Contaminants}

Geochemical processes may act on waters from different sources (and the contaminants they carry) once they enter the glacial deposits. Three chemical factors that affect contaminant concentrations beneath Woodbury are (1) oxic conditions, (2) localized consumption of dissolved oxygen in groundwater, and (3) radioactive decay.

Oxic conditions. Oxygen content of groundwater is a major control on whether specific contaminants are delayed, transformed, or mobilized in the subsurface. In the oxic conditions that are characteristic of the local groundwaterdissolved oxygen concentrations of at least $1 \mathrm{mg} / \mathrm{L}$ - the contaminant nitrate is not degraded and can be transported long distances. Thus, elevated nitrate concentrations (as high as $19 \mathrm{mg} / \mathrm{L}$ and exceeding the health-based MCL of $10 \mathrm{mg} / \mathrm{L}$ ) were found in the monitoring wells that tap oxic waters and are downgradient from nitrate sources such as septic-tank drainfields. In contrast to their effect on nitrate, the oxic conditions of the aquifer limit the mobility of the trace elements iron, manganese, and arsenic, which adhere to aquifer sediments. Thus, it is not surprising that concentrations of dissolved arsenic were generally less than the minimum reporting limit of $0.2 \mu \mathrm{g} / \mathrm{L}$ in the study area.

Localized consumption of dissolved oxygen. The mobility scenarios described above are reversed in isolated areas of the aquifer that contain either (1) an abundance of natural organic matter in the sediments or (2) high concentrations of dissolved organic carbon (DOC) derived from septic-system leachate (likely from improperly designed or overloaded systems). Because microbial respiration consumes oxygen when organic carbon is available, localized "anoxic" conditionsdissolved oxygen concentrations less than $0.5 \mathrm{mg} / \mathrm{L}$ - were observed in such areas. In these anoxic zones, nitrate is converted to harmless nitrogen gas in a process called denitrification. (This explains why water samples collected downgradient from some septic drainfields contained no detectable nitrate (fig. 3).) Also, in localized anoxic settings, iron coatings on aquifer sediments can dissolve, releasing into groundwater the iron as well as the manganese, arsenic, and other trace metals that are associated with the sediment coatings. Evidence of this process in the glacial deposits is the detection of arsenic 
in eight groundwater samples: the monitoring wells that contained the highest arsenic concentrations (maximum of 5.8 $\mu \mathrm{g} / \mathrm{L}$ ) had low dissolved oxygen concentrations (less than $2 \mathrm{mg} / \mathrm{L}$ ) and (or) high iron or manganese concentrations (greater than $100 \mu \mathrm{g} / \mathrm{L}$ and greater than $50 \mu \mathrm{g} / \mathrm{L}$, respectively). Some of the highest arsenic and iron concentrations in groundwater samples were from areas where aquifer sediments appear to be derived from the organic-rich limestone unit of the Cass Formation. These findings indicate that although arsenic is not a problem in water from the public-supply well selected for study, it could be if a new supply well were screened through a locally organicrich zone of the aquifer.

Radioactive decay. Despite the general absence of dissolved uranium in groundwater in the glacial deposits, the analysis of glacial aquifer sediments revealed an abundance of uranium associated with iron coatings on grains. This large source of uranium in aquifer sediments is likely the source for radon in groundwater in the Woodbury area. Radon is one of the products formed by radioactive decay of the parent material uranium-238. As of December 2009, the U.S. Environmental Protection Agency had not finalized regulations setting an MCL for radon in drinking water. All groundwater samples collected for this study had radon concentrations that exceeded the proposed MCL of 300 pCi/L (U.S. Environmental Protection Agency, 2009). Radon concentrations in the glacial deposits (490 to $2,400 \mathrm{pCi} / \mathrm{L})$ were not as high as those of the bedrock wells (1,600 to 13,000 $\mathrm{pCi} / \mathrm{L})$; concentrations in the metamorphic uplands were particularly high. Three of the four bedrock water samples exceeded the alternate MCL of $4,000 \mathrm{pCi} / \mathrm{L}$ that is proposed for states or water systems that agree to develop programs to address the health risks from radon in indoor air (U.S. Environmental Protection Agency, 2009). The high radon concentrations seen in the valley glacial deposits cannot be derived from the upland bedrock because it would take years for groundwater to flow from the uplands to the valley, while the time required for radon to decrease by half due to radioactive decay is only 3.8 days.

\section{Protection Effort Implications}

Water-quality protection in this setting depends on the entire community. The actions of individual residents influence water quality in the aquifer, as demonstrated, for example, by the number of monitoring wells that were found to be affected by septic-system leachate. If residents and businesses take steps to reduce input of manmade contaminants to groundwater, a positive effect on quality of the supply-well water might begin to be seen in less than 10 years, owing to the short residence time of water in the aquifer.

\section{Contacts}

Sandra Eberts, Team Leader

(614) 430-7740,smeberts@usgs.gov

Jeffrey Starn, Groundwater Flow

Modeling

(860) 291-6746,jjstarn@usgs.gov

Craig Brown, Geochemistry

(860) 291-6766, cjbrown@usgs.gov

\section{References}

Brown, C.J., Starn, J.J., Stollenwerk, K.G., Mondazzi, R.A., and Trombley, T.J., 2009, Aquifer chemistry and transport processes in the zone of contribution to a public-supply well in Woodbury, Connecticut, 2002-06: U.S. Geological Survey Scientific Investigations Report 2009-5051, 158 p.

Connecticut Department of Public Health, 2003, Source water assessment report for United Water Connecticut Woodbury System well \#2 wellfield: 4 p., accessed October 12, 2009, at http://www.dir.ct.gov/dph/Water/SWAP/ Community/CT1680011.pdf.

Geraghty \& Miller, Inc., 1979, A preliminary evaluation of a ground-water contamination problem in Woodbury, Connecticut.
Hamilton, P.A., Miller, T.L., and Myers, D.N., 2004, Water quality in the Nation's streams and aquifers-Overview of selected findings, 1991-2001: U.S. Geological Survey Circular 1265, 20 p.

Lyford, F.P., Carlson, C.S., Brown, C.J., and Starn, J.J., 2007, Hydrogeologic setting and ground-water flow simulation of the Pomperaug River Basin regional study area, Connecticut, in Paschke, S.S., ed., 2007, Hydrogeologic settings and ground-water flow simulations for regional studies of the transport of anthropogenic and natural contaminants to public-supply wellsStudies begun in 2001: U.S. Geological Survey Professional Paper 1737-A, p. 6-1 through 6-26.

Mazzaferro, D.L., 1986, Ground-water availability and water quality in Southbury and Woodbury, Connecticut: U.S. Geological Survey Water-Resources Investigations Report 84-4221, 105 p.

McMahon, P.B., Böhlke, J.K., Kauffman, L.J., Kipp, K.L., Landon, M.K., Crandall, C.A., Burow, K.R., and Brown, C.J., 2008, Source and transport controls on the movement of nitrate to public supply wells in selected principal aquifers of the United States: Water Resources Research, v. 44, W04401, 17 p.

Sovereign Consulting, Inc., 2004, Woodbury Mobil subsurface investigation report_-Woodbury Mobil/Middle Quarter Mall Area: Sandy Hook, Conn.

Starn, J.J., and Brown, C.J., 2007, Simulations of ground-water flow and residence time near Woodbury, Connecticut: U.S. Geological Survey Scientific Investigations Report 2007-5210, 45 p.

U.S. Environmental Protection Agency, 2009, Proposed radon in drinking water rule: Accessed August 10, 2009 , at http://www.epa.gov/ogwdw/radon/ proposal.html.

-By Martha L. Jagucki, Craig J. Brown, J. Jeffrey Starn, and Sandra M. Eberts

For more information on the Transport of Anthropogenic and Natural Contaminants to Supply Wells (TANC) topical study, see http://oh.water.usgs.gov/tanc/NAWQATANC.htm 